\title{
ON THE USAGE PATTERNS OF ONLINE SOCIAL NETWORKS AMONG B.ED. STUDENTS IN HARYANA
}

\author{
Dr. Ranjeet $\operatorname{Kaur}^{1} \& V_{\text {VandanaKhatkar }}^{2}$
}

Abstract-Research study being reported in this article has been designed to study usage patterns and differences therein, if any, in the use Online Social Media services (OSM) by the students of Bachelor of Education programme of Haryana. The findings being reported in this communication are a part of doctoral research being carried out by the researcher(s) at $\mathrm{Ch}$. Devi Lal University, Sirsa. Two attributes of OSM usage, namely, number of unique online friends and average daily duration spent online, have been studied. The research instrument was administered to a random sample of 300B.Ed. who have an active account on social media. Research hypotheses were tested using student's " $t$ " test. Research findings have shown quite significant differencesbetween (1) male and female students, and (2) rural and urban students in terms of (1) number of friends in virtual space and (2) time spent using online social media.

\section{INTRODUCTION}

Since its early days, the Internet has grown exponentially. However, unlike the early days when only scientists used it, people use the Internet today in a variety of different ways, including communicating with friends, family, and co-workers. In addition to connecting with current friends and family, people also use the Internet to form new relationships. As a result, some researchers have begun to describe the Internet as a social medium (Madden \&Lenhart, 2006).

The evolution and expansion of the Internet and the World Wide Web (WWW) and related technologies and their adoption as the preferred means of communication has resulted in to an overwhelmingly large worldpopulation use online social media (OSM) as communication and connectivity tool. OSMs and social networking sites (SNSs) are online communities of Internet users who want to communicate with other users about areas of mutual interest, whether from a personal, official, governance or academic perspective (Boyd, 2008).

Plethora of OSM services have transformed the thoughtof global village into a reality whereby billions of people communicate through socialnetworking sites. Numerous benefits have been obtained through distant communication through the use of social networking sites. Topics of discussion on social media forums range from personal to community to government to security to entertainment to educational and academic.

Researchers have examined the effects of the Internet on social involvement and psychological well-being way back in 1998. In Kraut, et al. (1998) the study has shown that the sample population has used the Internet extensively for communication. They have established that greater use of the Internet was associated with declines in participants' communication with family members in the household, declines in the size of their social circle, and increases in their depression and loneliness. These findings have implications for research, for public policy, and for the design of technology.

\section{RELATED RESEARCH}

According to Lenhart et al. (2015), American teens' making friends isn't just confined to the school yard, playing field or neighborhood - many are making new friends online. Fully 57\% of teens ages 13 to 17 have made a new friend online, with $29 \%$ of teens indicating that they have made more than five new friends in online venues. Most of these friendships stay in the digital space; only $20 \%$ of all teens have met an online friend in person. Boys are more likely than girls to make online friends: $61 \%$ of boys compared to $52 \%$ of girls have done so. Older teens are also more likely than younger teens to make online friends. Some $60 \%$ of teens ages 15 to 17 have met a friend online, compared with $51 \%$ of 13 -to-14-year-olds.

Khan et al. (2016) have assessed social media applications from view point of number of publications associated with each social media, in order to identify which social media has contributed most to the academic research. Further they have attempted to find a correlation between number of publications and development tools available on social media platforms. Researchers have ranked these applications with respect to number of times other social media share content with respective social applications.

\footnotetext{
${ }^{1}$ Assistant Professor, Department of Education, Chaudhary Devi Lal University, Sirsa (INDIA) - 125055

${ }^{2}$ Research Scholar, Department of Education, Chaudhary Devi Lal University, Sirsa (INDIA) - 125055, email: vandanasinghkuk@gmail.com
} 
According to a 2016 report published by Statista, there were about 3.5 billion Internet users in 2016 i.e. about 45 percent of the global population. China, India and USA occupied the top three positions (in that order) in terms of number of users. 83\% of female Internet users are on Facebook as compared to well as $75 \%$ of male internet users.

A 2017 Statista report on the global number of monthly active Facebook users ${ }^{3}$ reveals that there were 2.006 billion users at the end of second quarter of 2017. As on January 2017, 18\% of the global Facebook users were male in the age group of 1824 years as compared to $12 \%$ female in the same age group. The report further says $53 \%$ of the online US population visits the Facebook several times a day whereas once-a-day users are $17 \%$ of the online population.

\section{RESEARCH PROBLEM AND OBJECTIVES}

With the Internet shackling going off with the withdrawal of govt. control in late eighties and advent of social media sites in the 2000s, it is assumed in some quarters that the social interaction and academic performance of students is facing a lot of neglect and challenges. Students are spending increasingly more time on this new media with increasingly more number of online friends - whom they may or may not know in person.

This research communication studies the variationsin the social media usage practices, if any, between vertical groupings of B.Ed. students ${ }^{4}$ in terms of total number of unique friends in online communities and average daily time spent using social media services. Accordingly, the research problem was stated as follows: "On the usage patterns of online social networks among B.Ed. students in Haryana."

Keeping in line with the problem stated above following research objectives were set:

Objective 1: To ascertain the difference in B.Ed. students' usage of social media networks by gender.

Objective 2: To ascertain the difference in B.Ed. students' usage of social media networks by locality of residence i.e. rural and urban.

There might be numerous attributes of social media usage, like frequency of daily visit to SNS, average daily time spent using SNS, number of unique friends on SNS, number of SNS accounts etc. Although data relating to a number of attributes have been collected during the web-based survey, yet the present research has been delimited to only two aspects of social media usage, namely, (1) average daily time spent using social networks, and (2) number of unique friends on social networks.

\section{RESEARCH QUESTIONS AND HYPOTHESES}

This research has been focused to study differences in patterns of online media usage amongst B.Ed. students of different genders, streams and levels of education. Usage pattern of OSM spans over several aspects like number of OSM subscribed, devices used for access, number of unique online friends, period of membership, frequency of daily OSM visit/use, and duration of daily use, etc.In the present research communication, differences and disparities, if any, between male-female and rural-urban users in respect to number of online friends and duration of daily usage have been studied.

\subsection{Research questions}

Keeping in mind the broad objectives, following research questions and corresponding null hypotheses have been formulated:

Q1: To what extent - whether statistically significant or not - do the B.Ed. students exhibit variations in number of friends in online virtual communities on the bases of gender and location of residence?

Q2: To what extent - whether statistically significant or not - do the B.Ed. students exhibit variations in duration of social media usage on the bases of gender and location of residence?

\subsection{Research hypotheses}

H1: There is no significant difference between male and female B.Ed. students in terms of total number of unique friends on the online social media.

H2: There is no significant difference between rural and urban B.Ed. students in terms of total number of unique friends on the online social media.

H3: There is no significant difference between male and female B.Ed. students in terms of average daily use of online social media.

H4: There is no significant difference between rural and urban B.Ed. students in terms of average daily use of online social media.

\section{RESULT AND DISCUSSION}

\footnotetext{
${ }^{3}$ Active users are those which have logged in to Facebook during the last 30 days.

${ }^{4}$ The sample population - B.Ed. students using social media services - have been vertically divided in two groups each based on gender (male and female) and locality of their residence (urban and rural).
} 
Following four tables houses the results of application of student's t-test on the sample data. Format of all the table is same. First and seconds rows of the tables contain mean and standard deviation respectively of two groups of population; whereas third and fourth rows show sample/group size and $t$ value.

Table 1. Results of t-test (number of friends vs. male-female users)

\begin{tabular}{|c|c|c|}
\hline Parameter & $\begin{array}{l}\text { Group One } \\
\text { Male Users }\end{array}$ & $\begin{array}{c}\text { Group Two } \\
\text { Female Users }\end{array}$ \\
\hline Mean & 111.94 & 48.21 \\
\hline $\mathrm{SD}$ & 51.41 & 35.81 \\
\hline $\mathrm{N}$ & 150 & 150 \\
\hline $\mathrm{t}$ & & \\
\hline
\end{tabular}

The $t$ value is 12.4580 at significance level of 0.05 , i.e., confidence interval of 95 . By conventional criteria, this difference is considered to be extremely statistically significant. And the null hypothesis $\mathrm{H}_{1}$ is rejected, thereby implying that there exists a significant difference between male and female social media user students of B.Ed. in terms of in total number of unique friends on online communities.

Further, results as shown in Table 1 depict that on an average a male B.Ed. student has about 63 more online friends in comparison to their female counterparts. Also, a difference of about 16 in the values of standard deviations depicts a wider range of number of online friends in case of male B.Ed, students as compared to female students.

Table 2. Results of t-test (number of friends vs. rural - urban users)

\begin{tabular}{|c|c|c|}
\hline Parameter & $\begin{array}{c}\text { Group One } \\
\text { Rural users }\end{array}$ & $\begin{array}{c}\text { Group Two } \\
\text { Urban users }\end{array}$ \\
\hline \hline Mean & 65.33 & 94.06 \\
\hline $\mathrm{SD}$ & 41.95 & 61.16 \\
\hline $\mathrm{N}$ & 146 & 154 \\
\hline $\mathrm{t}$ & \multicolumn{2}{|c|}{4.7197} \\
\hline
\end{tabular}

The $t$ value of the unpaired t-test comes out to be 4.7197 at significance level of 0.05 . The null hypothesis stands rejected, for the result is quite significant. Rejection of null hypothesis $\mathrm{H}_{2}$ leads to the conclusion that there exists a significant difference between rural and urban B.Ed. social media using students of B.Ed. with regards to total number of unique friends on online social media services.

Results contained in Table 2 also shows that on an average the urban students have about 39 more online friends in comparison to their rural counterparts. Further, a higher values of standard deviation (by about 20 points) for urban students indicates a wider range of online friends in case of urban students.

Table 3. Results of t-test (duration of usage vs. male - female users)

\begin{tabular}{|c|c|c|}
\hline Parameter & $\begin{array}{l}\text { Group One } \\
\text { Male Users }\end{array}$ & $\begin{array}{c}\text { Group Two } \\
\text { Female Users }\end{array}$ \\
\hline \hline Mean & 2.58 & 2.14 \\
\hline $\mathrm{SD}$ & 1.18 & 1.05 \\
\hline $\mathrm{N}$ & 150 & 150 \\
\hline $\mathrm{t}$ & & \\
\hline
\end{tabular}

Results of unpaired t-test $(t$ value $=3.4078$ and $\mathrm{p}$ value $=0.0007)$ at 0.05 significance level has ledto rejection of null hypothesis $\mathrm{H}_{3}$ which may be interpreted as "there is a significant difference between male and female user-students of B.Ed. in terms of average daily usage of online social media services."Further, it could also be made out that male students spend more time using social media services than female students, and the variation in usage hours of individual male students is more than the variations in usage time of individual female students.

Table 4. Results of t-test (duration of usage vs. rural - urban users)

\begin{tabular}{|c|c|c|}
\hline Parameter & $\begin{array}{c}\text { Group One } \\
\text { Rural users }\end{array}$ & $\begin{array}{c}\text { Group Two } \\
\text { Urban users }\end{array}$ \\
\hline \hline Mean & 1.83 & 2.86 \\
\hline SD & 0.76 & 1.21 \\
\hline
\end{tabular}




\begin{tabular}{|c|c|c|}
\hline $\mathrm{N}$ & 146 \\
\hline $\mathrm{t}$ & 8.8288 \\
\hline
\end{tabular}

Results of unpaired t-test ( $t$ value $=8.8288$ and $p$ value less than 0.0001$)$ at 0.05 significance level lead to rejection of null hypothesis $\mathrm{H}_{4}$ which may be interpreted as "there is an extremely significant difference between rural and urban students B.Ed. in terms of usage hours on online social media. Further, urban users spend more time using social media and their usage durations are more widely spread as indicated by a higher value of standard deviation (1.21) for urban students in comparison to rural students' standard deviation of 0.76 .

\section{CONCLUSION AND FURTHER WORK}

The research study included serving a questionnaire to 300 B.Ed. students who have accounts registered with social networking sites like Facebook, Twitter, etc. The study was aimed at ascertaining the differences in the social media using habits between male \& female students and between rural \& urban students. Differences between the target groups have been studied from viewpoints of number of social media friends and average daily time spent online using social media services. All the four research hypotheses - null hypotheses - laid down in section 4.2 have been rejected on the basis of results of students' t-test, thereby meaning that male \& female and rural \& urban B.Ed. students exhibit a significantly different social networking behavior in terms on number of friends espoused on these media and time spent using these media.

Research findings have shown that male B.Ed. students have more friends on social networks and they spend more time using these network in comparison to their female counterparts. Similarly, B.Ed. students from urban areas have espoused more friends on social networks and they spend more time using social networks vis-à-vis B.Ed. students from rural areas.

Owing to space and time limitations only two demographic aspects of the target population and only two aspects of social media usage have been covered in the present research report. Present research can be furthered by studying the effect of other demographics aspects like educational level and stream on the social media usage. Similarly, other aspects of media usage like frequency of daily visits to social sites and number of social accounts etc. may also be studied.

\section{REFERENCES}

[1] Kraut, R., Patterson, M., Lundmark, V.,Kiesler, S., Mukopadhyay, T., and Scherlis, W. (1998),"Internet paradox: A social technology that reduces social involvement and psychological wellbeing,” American Psychologist, vol. 53, no. 9, pp. 1017-1031. (2000), "Information and communication: Alternative uses of the Internet in households," Information Systems Research, 10, 287-303.

[3] Deborah Fallows (2005), How Women and Men Use the Internet, The Pew Internet \& American Life Project, retrieved on February 10, 2017 from URL http://www.pewinternet.org/files/2005/12/PIP_Women_and_Men_online.pdf.

[4] Madden, M.andLenhart, A. (2006),“Online Dating,” Pew Internet \& American Life Project, retrieved on January 25, 2017 from URL:http://www.pewInternet.org/pdfs/PIP_Online_Dating.pdf.

[5] Boyd, D. (2008), "Why youth (heart) social network sites: The role of networked publics in teenage social life,"in Buckingham, D. (Ed.), "Youth, Identity, and Digital Media," pp. 119-142, Cambridge, MA: MIT Press.

[6] Lenhart, A., Smith, A., Anderson, M., Duggan, M., and Perrin, A. (2015), “Teens, Technology and Friendship,” Pew Research Centre, retrieved on January 30, 2017 from URL http://www.pewinternet.org/files/2015/08/Teens-and-Friendships-FINAL2.pdf.

[7] Khan, M.M., Ghani, I., Jeong, S. R., Ibrahim, R. and Habib-ur-Rehman (2016), "Social Media Usage in Academic Research," Journal of Theoretical and Applied Information Technology, Vol. 87, No. 2. 